\title{
Stability of the $\mathrm{H}$-cluster under whole-cell conditions-formation of an $\mathrm{H}_{\text {trans }}$-like state and its reactivity towards oxygen
}

\author{
Marco Lorenzi ${ }^{1} \cdot$ Pierre Ceccaldi $^{1,2} \cdot$ Patricia Rodríguez-Maciá $^{3,4} \cdot$ Holly Jayne Redman $^{1} \cdot$ Afridi Zamader $^{1,5}$. \\ James A. Birrell ${ }^{3} \cdot$ Livia S. Mészáros ${ }^{1} \cdot$ Gustav Berggren ${ }^{1}$ (1)
}

Received: 20 September 2021 / Accepted: 3 January 2022 / Published online: 8 March 2022

(c) The Author(s) 2022

\section{Abstract}

Hydrogenases are metalloenzymes that catalyze the reversible oxidation of molecular hydrogen into protons and electrons. For this purpose, $[\mathrm{FeFe}]$-hydrogenases utilize a hexanuclear iron cofactor, the $\mathrm{H}$-cluster. This biologically unique cofactor provides the enzyme with outstanding catalytic activities, but it is also highly oxygen sensitive. Under in vitro conditions, oxygen stable forms of the $\mathrm{H}$-cluster denoted $\mathrm{H}_{\text {trans }}$ and $\mathrm{H}_{\text {inact }}$ can be generated via treatment with sulfide under oxidizing conditions. Herein, we show that an $\mathrm{H}_{\text {trans }}$-like species forms spontaneously under intracellular conditions on a time scale of hours, concurrent with the cells ceasing $\mathrm{H}_{2}$ production. Addition of cysteine or sulfide during the maturation promotes the formation of this $\mathrm{H}$-cluster state. Moreover, it is found that formation of the observed $\mathrm{H}_{\text {trans }}$-like species is influenced by both steric factors and proton transfer, underscoring the importance of outer coordination sphere effects on H-cluster reactivity.

\section{Graphical abstract}

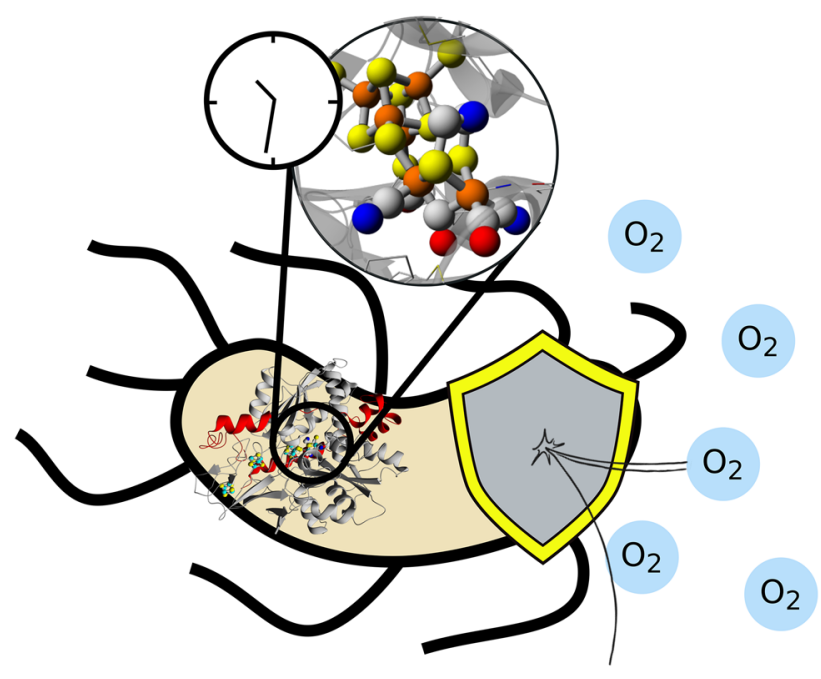

Keywords Metalloenzymes $\cdot$ Hydrogenase $\cdot$ Enzyme mechanism $\cdot$ Electron paramagnetic resonance (EPR) $\cdot$ Biophysics

Gustav Berggren

Gustav.Berggren@kemi.uu.se

Extended author information available on the last page of the article

\section{Introduction}

Hydrogen gas $\left(\mathrm{H}_{2}\right)$ is a promising energy vector for the coming energy transition, due to its high energy/mass ratio and clean combustion [1,2]. As of today, the lack of a cheap and efficient catalyst for $\mathrm{H}_{2}$ production prevents any 
possible large-scale application, since currently available technologies all rely on rare or precious elements [3-6]. [FeFe]-hydrogenases (Fig. 1A) are central to hydrogen metabolism in many microorganisms, as they catalyze both $\mathrm{H}_{2}$ oxidation and evolution [7]. Since their $\mathrm{H}_{2}$ evolution rates are as high as $10,000 \mathrm{~s}^{-1}$, these enzymes are also highly relevant in the context of developing sustainable biological and bio-inspired synthetic systems for $\mathrm{H}_{2} / \mathrm{H}^{+}$interconversion $[1,2,8-11]$. The active site of [FeFe]-hydrogenases (the H-cluster, Fig. 1B) contains a unique diiron subcluster $\left([2 \mathrm{Fe}]_{\mathrm{H}}\right.$ ) where the low valent $\mathrm{Fe}$ ions are bridged by a bidentate azadithiolate ligand $\left({ }^{-} \mathrm{SCH}_{2} \mathrm{NHCH}_{2} \mathrm{~S}^{-}\right.$, adt) and further coordinated by three $\mathrm{CO}$ and two $\mathrm{CN}^{-}$ligands $[2,12-15]$. The $[2 \mathrm{Fe}]_{\mathrm{H}}$ subsite is, in turn, attached to a canonical $[4 \mathrm{Fe}-4 \mathrm{~S}]$ cluster ([4Fe$4 \mathrm{~S}]_{\mathrm{H}}$ ) through a cysteine residue. The ligand geometry of the H-cluster leaves an open-coordination site on the $[2 \mathrm{Fe}]_{\mathrm{H}}$ subsite positioned in close proximity to the nitrogen of the adt ligand, and the latter is believed to act as a proton relay during catalysis. [FeFe]-hydrogenases are extremely $\mathrm{O}_{2}$ sensitive enzymes, and this sensitivity represents a key challenge for technological development. The precise inactivation mechanism is still under debate, but $\mathrm{O}_{2}$ is, with few exceptions, an irreversible inhibitor of the enzyme [16-21]. However, it is possible to protect the $\mathrm{H}$-cluster by forming a reversibly inhibited state, as first observed already in the 1980 s in the $[\mathrm{FeFe}]$-hydrogenases from sulfate reducing bacteria including Desulfovibrio vulgaris and Desulfovibrio desulfuricans (DvHydAB and $D d \mathrm{Hyd} \mathrm{AB}$, respectively, whose protein sequences are identical), following isolation of the enzymes under aerobic conditions [22-25]. The chemical nature of this $\mathrm{O}_{2}$ stable form has since then been characterized in-depth under in vitro conditions [20,26-30]. The catalytically active, but $\mathrm{O}_{2}$ sensitive, $\mathrm{H}_{\mathrm{ox}}$ state has been observed in all $[\mathrm{FeFe}]$-hydrogenases studied so far, and it exhibits an
$[\mathrm{Fe}(\mathrm{II}) \mathrm{Fe}(\mathrm{I})]_{\mathrm{H}}$ subsite while the $[4 \mathrm{Fe}-4 \mathrm{~S}]_{\mathrm{H}}$-cluster resides in the oxidized $(2+)$ state $[2,9,13,27]$ (Fig. 1B). The $\mathrm{H}_{\mathrm{ox}}$ state is also well-known for its affinity for $\mathrm{CO}$, generating the reversibly inhibited $\mathrm{H}_{\mathrm{ox}}-\mathrm{CO}$ state $[31,32]$. In $D d \mathrm{HydAB}$ the coordination of a sulfide ligand $\left(\mathrm{SH}^{-}\right)$to the $[2 \mathrm{Fe}]_{\mathrm{H}}$ subsite converts $\mathrm{H}_{\mathrm{ox}}$ into the isoelectronic $\mathrm{H}_{\text {trans }}$ state $\left([4 \mathrm{Fe}-4 \mathrm{~S}]_{\mathrm{H}}{ }^{+}-[\mathrm{Fe}(\mathrm{II}) \mathrm{Fe}(\mathrm{II})-\mathrm{SH}]_{\mathrm{H}}\right)$, which instead of degrading upon $\mathrm{O}_{2}$ exposure is oxidized to the so-called $\mathrm{H}_{\text {inact }}$ state $\left([4 \mathrm{Fe}-4 \mathrm{~S}]_{\mathrm{H}}{ }^{2+}-[\mathrm{Fe}(\mathrm{II}) \mathrm{Fe}(\mathrm{II})-\mathrm{SH}]_{\mathrm{H}}\right)$, also referred to as $\mathrm{H}_{\text {ox }}$ air $[33,34]$ (Fig. 1B). Albeit an inhibited state, the $\mathrm{H}_{\text {inact }}$ state is readily reactivated following release of the sulfide ligand under reducing conditions [19, 27, 29, 35].

Despite having been widely studied in purified form, our insight into the catalytic cycle and stability of [FeFe]hydrogenases in a cellular environment remains limited. Improved understanding of [ $\mathrm{FeFe}]$-hydrogenase reactivity under whole-cell conditions is critical not only to verify the physiological relevance of states observed in vitro, but also to improve the performance of hydrogenase-based biological and biohybrid energy applications. Herein, we take advantage of our capacity to generate semi-synthetic [FeFe]-hydrogenases in E. coli at concentrations suitable for whole-cell spectroscopy [9, 36-38], to investigate the formation of the $\mathrm{H}_{\text {trans }}$ and $\mathrm{H}_{\text {inact }}$ states under intracellular conditions. More specifically, we explore two different model enzymes: HydA1 from the green algae Chlamydomonas reinhardtii $(\mathrm{CrHydA} 1)$ and the aforementioned bacterial $D d$ HydAB. Moreover, a recent mechanistic proposal underscores the need for efficient protontransfer during the formation of these sulfide-inhibited states [34]. Thus, we probe the influence of sterics and the proton-transfer network on the inhibition chemistry of the $\mathrm{CrHydA} 1$ enzyme, through modifications of the organometallic cofactor as well as single-point mutations in the active-site pocket.
Fig. 1 Schematic representation of [FeFe]-hydrogenase and the H-cluster. A The dimeric Desulfovibrio desulfuricans [FeFe]hydrogenase $(D d \mathrm{HydAB})$ in the $\mathrm{H}_{\text {inact }}$ state, based on the crystal structure reported in ref [33] (PDB ascension number 6SG2). Subunit A is colored in gray, subunit B is colored in red, the color scheme for the $\mathrm{H}$-cluster and for the accessory $[\mathrm{FeS}]$ clusters is based on the elements (Fe: cyan; S: yellow; $\mathrm{N}$ : blue; O: red; C: gray). B The H-cluster in the catalytically active state $\mathrm{H}_{\mathrm{ox}}$ and in the inhibited state $\mathrm{H}_{\text {inact }}$

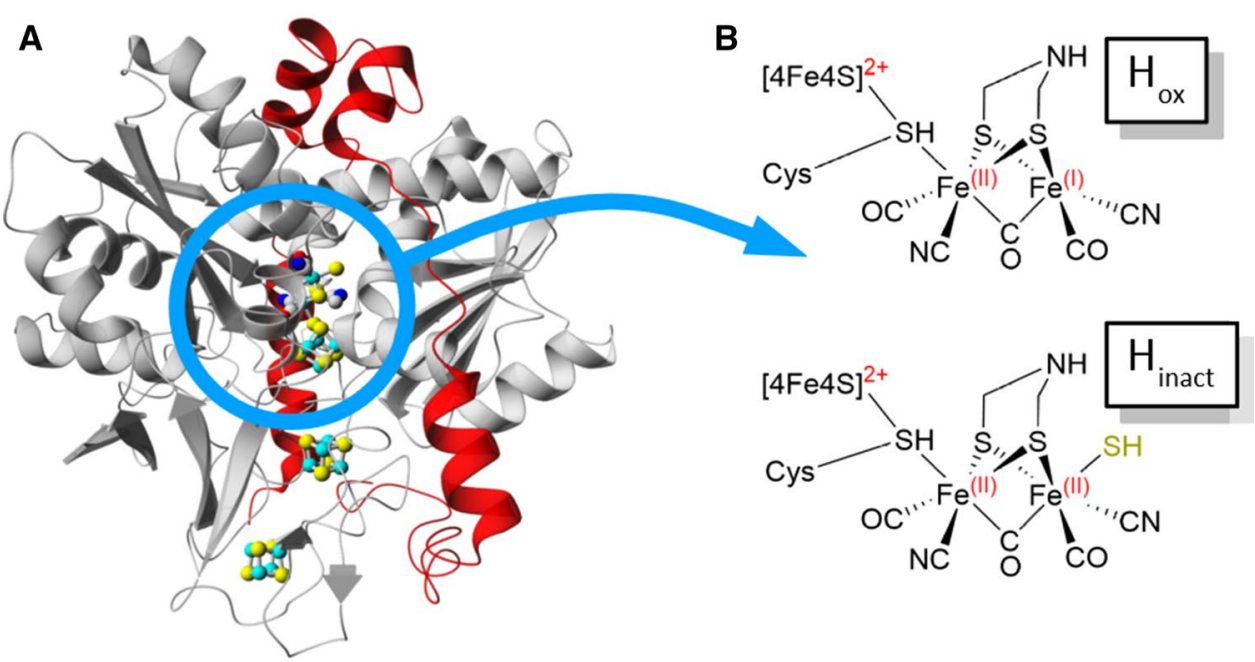




\section{Results and discussion}

\section{Formation of an $\mathrm{H}_{\text {trans }}$-like state under whole-cell conditions}

To generate enzyme concentrations enabling H-cluster detection by electron paramagnetic resonance (EPR) spectroscopy $\mathrm{CrHydA} 1$ was heterologously expressed in standard E.coli BL21, as previously described [36-39]. As $E$. coli does not natively express an [FeFe]-hydrogenase, the organism lacks the [FeFe]-hydrogenase-specific accessory proteins (HydEFG) and produces the enzyme in an inactive form, complete with the $[4 \mathrm{Fe}-4 \mathrm{~S}]_{\mathrm{H}}$ cluster but lacking the diiron $[2 \mathrm{Fe}]_{\mathrm{H}}$ cofactor (apo-CrHydA1) [40-42]. After protein overproduction, cell cultures were concentrated and the active semi-synthetic enzyme (holo$\mathrm{CrHydA} 1$, herein denoted [2Fe $\left.]^{\text {adt }} \mathrm{CrHydA} 1\right)$ was subsequently generated through the addition of the synthetic $[2 \mathrm{Fe}]_{\mathrm{H}}$ cofactor mimic $\left[\mathrm{Fe}_{2}(\mathrm{adt})(\mathrm{CO})_{4}(\mathrm{CN})_{2}\right]^{2-}\left([2 \mathrm{Fe}]^{\text {adt }}\right)$ under strictly anaerobic conditions. The final concentration of $[2 \mathrm{Fe}]^{\text {adt }}$ in the cell suspension was $80 \mu \mathrm{M}$, as this has previously been shown to afford close to quantitative maturation of apo- $\mathrm{CrHydA} 1$ under these conditions $[36-39,43]$. The cell suspensions produced $\mathrm{H}_{2}$ for $1-2 \mathrm{~h}$ following the addition of $[2 \mathrm{Fe}]^{\text {adt }}$, before slowing down

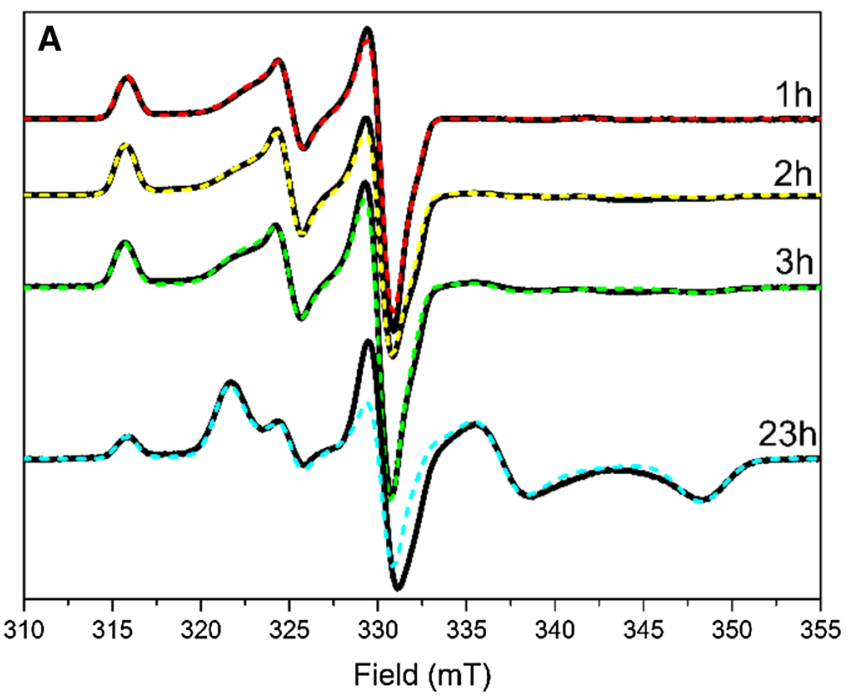

Fig. 2 The effect of time on the population of H-cluster states in $[2 \mathrm{Fe}]^{\text {adt }}-\mathrm{CrHydA} 1$ monitored by EPR spectroscopy. A Whole-cell EPR spectra of $[2 \mathrm{Fe}]^{\text {adt }}-C r$ HydA 1 recorded on samples of $E$. coli cells expressing apo-CrHydA1 and flash frozen following incubation with the $[2 \mathrm{Fe}]^{\text {adt }}$ cofactor for $1 \mathrm{~h}, 2 \mathrm{~h}, 3 \mathrm{~h}$ and $23 \mathrm{~h}$ at $37{ }^{\circ} \mathrm{C}$ under anaerobic conditions. Experimental spectra from a representative dataset are overlaid with simulations (dashed lines), including $\mathrm{H}_{\mathrm{ox}}$, $\mathrm{H}_{\mathrm{ox}}-\mathrm{CO}$ and $\mathrm{H}_{\text {trans }}$ contributions. All spectra were corrected by subtracting the apo-CrHydA1 control sample, to eliminate any signal significantly and halting production after 3-4 h (Fig. S1). In parallel to quantifying $\mathrm{H}_{2}$ production, whole-cell samples for EPR analysis were collected and flash frozen at different time points to monitor the formation and stability of the $[2 \mathrm{Fe}]^{\text {adt }}-\mathrm{CrHydA} 1$ holoenzyme over the course of $23 \mathrm{~h}$. EPR spectra recorded on samples obtained after a 20 min incubation with $[2 \mathrm{Fe}]^{\text {adt }}$ under an argon atmosphere displayed a mixture of one rhombic $\left(g_{z} \neq g_{y} \neq g_{x}\right)$ and one pseudo-axial $\left(g_{x}=g_{y} \neq g_{z}\right)$ feature, respectively attributable to the $\mathrm{H}_{\mathrm{ox}}\left(\mathrm{g}_{\mathrm{zyx}}=2.100,2.040,1.998\right)$ and to the CO-inhibited $\mathrm{H}_{\mathrm{ox}}-\mathrm{CO}$ states $\left(\mathrm{g}_{\| \perp}=2.054,2.007\right)$ [31] (Fig. 2). The $\mathrm{H}_{\mathrm{ox}}$ and $\mathrm{H}_{\mathrm{ox}}-\mathrm{CO}$ species continued to be the main constituents of the signal over the first $3 \mathrm{~h}$, with the latter species gradually releasing $\mathrm{CO}$ and converting into the $\mathrm{H}_{\mathrm{ox}}$ state. (Fig. 2B).

However, after $23 \mathrm{~h}$ of incubation, a significant decrease in the features specific to these two states is observed, concomitantly with the rise of a relatively broad rhombic signal with $\mathrm{g}_{\mathrm{zyx}}=2.064,1.972,1.910$. Simulations show that the latter species begins to form already after $2 \mathrm{~h}$ of incubation, at which point it represents $\sim 10 \%$ of the total spin count. This rhombic signal accumulates with time to then become the dominant species in the sample, contributing for $~ 80 \%$ of the total signal intensity after $23 \mathrm{~h}$. At this point, the cells are able to resume $\mathrm{H}_{2}$ production when re-suspended in fresh media containing glucose (Fig. S1); however, the

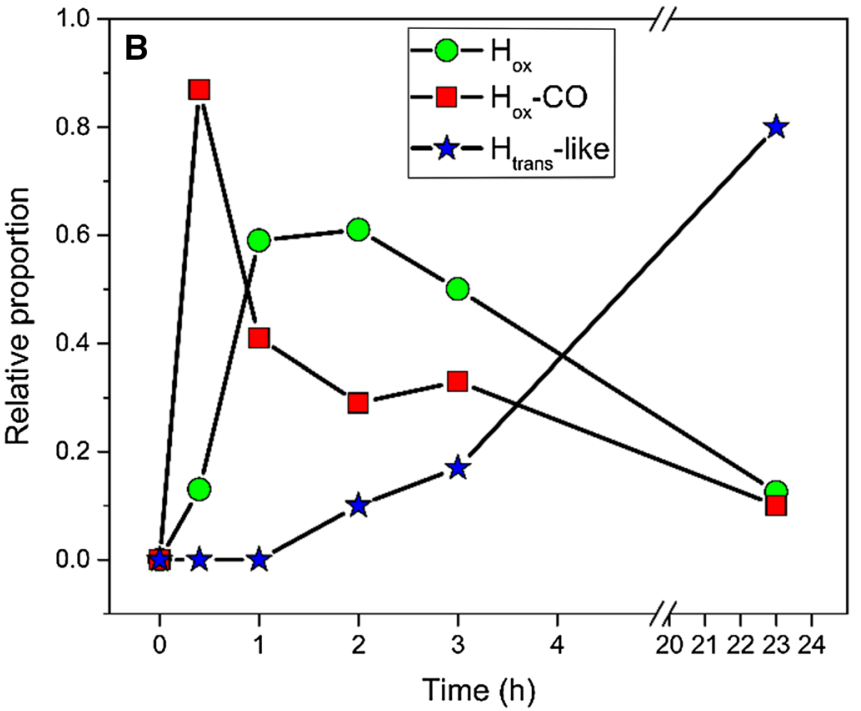

coming from the cells and from unmatured $\mathrm{CrHydA1}$ (Fig. S4). The poor fitting around $330 \mathrm{mT}$ on the $23 \mathrm{~h}$ spectrum is due to the imperfect subtraction of the variable $g=2.02$ isotropic signal arising from the cell background, which is a minor contribution in the difference spectrum (see Fig. S4). EPR experimental conditions: $\mathrm{T}=20 \mathrm{~K}, \mathrm{P}=1$ $\mathrm{mW}, \nu=9.28 \mathrm{GHz}$. B Contribution of the different catalytic states to the signal intensity at the different time points on the same dataset. The relative contributions are calculated based on their respective weight in the simulations 
media exchange has no effect on the relative proportion of the different states (Fig. S2). Similarly, the broad rhombic signal displayed negligible changes when parallel samples incubated for $23 \mathrm{~h}$ were exposed to strongly reducing conditions via the addition of sodium dithionite and $1 \mathrm{~atm} \mathrm{H}_{2}$ (data not shown). In combination, these observations suggest that, once formed, the species giving rise to the rhombic signal is highly stable. Thus, the $\mathrm{H}_{2}$ produced by aged cells is attributed to the small residual population still residing in the catalytically competent $\mathrm{H}_{\mathrm{ox}}$ state.

The broad rhombic EPR signal $\left(\mathrm{g}_{\mathrm{zyx}}=2.064,1.972\right.$, 1.910) was not observed when cells expressing apo$\mathrm{CrHydA1}$ were incubated for up to $23 \mathrm{~h}$ in the absence of $[2 \mathrm{Fe}]^{\text {adt }}$, nor in standard BL21 cells incubated with the same complex (Fig. S3), supporting the assignment of the signal to an H-cluster species. The g values of this new broad EPR signal are in good agreement with a signal previously attributed to the sulfide-inhibited $\mathrm{H}_{\text {trans }}$ state in $D d \mathrm{HydAB}$ $\left(\mathrm{g}_{\mathrm{zyx}}=2.060 ; 1.960 ; 1.890\right)[25,29]$. To assess whether the origin of this new signal could be attributed to the binding of a sulfide or hydrosulfide ligand to the diiron subcluster, $375 \mu \mathrm{M} \mathrm{Na}_{2} \mathrm{~S}$ were added to the incubation mixture concomitantly with $[2 \mathrm{Fe}]^{\text {adt }}$. The addition of sulfide increased the overall intensity of the rhombic $\mathrm{H}_{\text {trans }}$-like signal, as reported for the in vitro formation of the $\mathrm{H}_{\text {trans }}$ state in $D d \mathrm{HydAB}$ [34]. The same effect could be observed using L-cysteine as the source for the sulfide, albeit with a lower magnitude (Fig. S5).

\section{Intracellular $\mathrm{H}_{\text {trans }}$ formation in DdHydAB}

The heterodimeric $D d$ HydAB hydrogenase has been the primary model system for elucidating the chemistry of the $\mathrm{H}_{\text {trans }}$ and $\mathrm{H}_{\text {inact }}$ states $[29,33,34]$. Thus, this enzyme was also studied under intracellular conditions for comparative purposes, with $D d \mathrm{HydAB}$ overproduced in $E$. coli using the same methods as for $\mathrm{CrHydA}$. In addition to the $[4 \mathrm{Fe}-4 \mathrm{~S}]_{\mathrm{H}}$ component of the $\mathrm{H}$-cluster, $D d \mathrm{HydAB}$ features two additional [4Fe-4S] "F-clusters" serving as electron relays from the protein surface to the active site (Fig. 1A). The apo- $D d$ HydAB protein, containing only the three $[4 \mathrm{Fe}-4 \mathrm{~S}]$ clusters, shows an interaction spectrum of the $[4 \mathrm{Fe}-4 \mathrm{~S}]$ clusters' signals under intracellular conditions (Fig. 3, apo-DdHAB), as observed earlier for the purified enzyme [44]. In vitro activation of apo-DdHydAB using $[2 \mathrm{Fe}]^{\text {adt }}$ to generate $[2 \mathrm{Fe}]^{\text {adt }}-D d \mathrm{HydAB}$ (i.e. holo$D d \mathrm{HydAB})$ is a relatively slow process. The mechanistic rationale for this remains to be elucidated, but is arguably attributable to the relative stabilities of the so-called "open" and "closed" conformations of the enzyme [44]. Nevertheless, treating apo-DdHydAB expressing E. coli cells with $[2 \mathrm{Fe}]^{\text {adt }}$ for just $1 \mathrm{~h}$ yielded a complex spectrum,

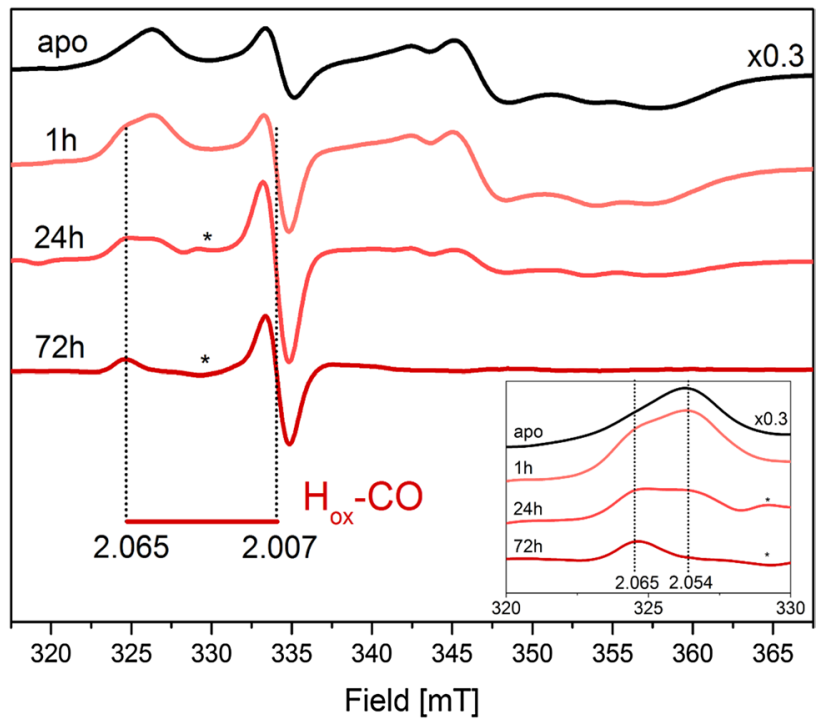

Fig. 3 The effect of time on the population of $\mathrm{H}$-cluster states in $[2 \mathrm{Fe}]^{\text {adt }}-D d \mathrm{HydAB}$ monitored by EPR spectroscopy. Whole-cell EPR spectra of apo- and $[2 \mathrm{Fe}]^{\text {adt }}-D d \mathrm{Hyd} \mathrm{AB}$ recorded on samples of $E$. coli cells expressing apo- $D d \mathrm{Hyd} \mathrm{AB}$ and flash frozen prior to or following incubation with the $[2 \mathrm{Fe}]^{\text {adt }}$ cofactor for $1 \mathrm{~h}, 24 \mathrm{~h}$ and $72 \mathrm{~h}$ under anaerobic conditions at $37^{\circ} \mathrm{C}$. The figure reports the $\mathrm{g}$ values for the $\mathrm{H}_{\mathrm{ox}}-\mathrm{CO}$ state. (Inset): zoom in on the $320-330 \mathrm{mT}$ area. Vertical dotted lines indicate the $\mathrm{g}=2.065$ feature belonging to $\mathrm{H}_{\mathrm{ox}}-\mathrm{CO}$ and the $\mathrm{g}=2.054$ from the $[4 \mathrm{Fe}-4 \mathrm{~S}]$ clusters interaction spectrum. Asterisks mark a feature attributable to the $\left(\mathrm{F}_{\text {red }}\right) \mathrm{H}_{\mathrm{ox}}$ interaction spectrum. EPR experimental conditions: $\mathrm{T}=20 \mathrm{~K}, \mathrm{P}=1 \mathrm{~mW}, \nu=9.28 \mathrm{GHz}$. Note that the spectrum of apo- $D d \mathrm{Hyd} \mathrm{AB}$ has been normalized by a factor 0.3

with an axial signature attributable to an $\mathrm{H}_{\mathrm{ox}}-\mathrm{CO}$ species clearly discernible under the dominant $[4 \mathrm{Fe}-4 \mathrm{~S}]$ interaction spectrum. The reason for the apparent higher rate of $\mathrm{H}$-cluster assembly in $D d \mathrm{HydAB}$ under whole-cell conditions is unknown. Extending the incubation time to $24 \mathrm{~h}$ resulted in a decrease of the $[4 \mathrm{Fe}-4 \mathrm{~S}]$ signals, possibly due to gradual oxidation, allowing also for the detection of a contribution arising from a small population of $[2 \mathrm{Fe}]^{\text {adt }}-D d \mathrm{HydAB}$ featuring the $\mathrm{H}$-cluster in the $\mathrm{H}_{\mathrm{ox}}$ state and a one-electron-reduced F-cluster (denoted $\left(\mathrm{F}_{\text {red }}\right)$ $H_{\text {ox }}$ ) [45]. However, no features attributable to $H_{\text {trans }}$ or an $\mathrm{H}_{\text {trans }}$-like state were observed, even when extending the incubation time to $72 \mathrm{~h}$, at which point the only remaining $\mathrm{H}$-cluster signal is $\mathrm{H}_{\mathrm{ox}}-\mathrm{CO}$ (Fig. 3). These experiments verify that $[2 \mathrm{Fe}]^{\text {adt }}-D d$ HydAB can be generated through artificial maturation under whole-cell conditions, at a seemingly faster rate than during normal in vitro studies. Still, the lack of any $\mathrm{H}_{\text {trans }}$-like species in the case of $D d$ HydAB shows that the stability of this state under intracellular conditions can vary significantly between different $[\mathrm{FeFe}]$-hydrogenases, as expected from variations in structure as well as reported affinities for other inhibitors such as carbon monoxide [46]. 


\section{Reactivity of the $\mathrm{H}_{\text {trans }}$-like state towards molecular oxygen.}

As mentioned in the introduction, in $D d \mathrm{HydAB}$ the $\mathrm{H}_{\text {inact }}$ state forms via $\mathrm{H}_{\text {trans }}$ under oxidative conditions (e.g. during aerobic purification) and has been demonstrated to grant protection from $\mathrm{O}_{2}$-induced $\mathrm{H}$-cluster degradation. Conversely, $\mathrm{CrHydA} 1$ is known to be an extremely oxygen-sensitive enzyme and aerobic purification of an active enzyme has not been reported [20]. Still, $C r H y d A 1$ has also been shown to be able to enter the $\mathrm{O}_{2}$-protected $\mathrm{H}_{\text {inact }}$ state under controlled in vitro conditions [34]. To examine if exposing whole-cell $[2 \mathrm{Fe}]^{\text {adt }}-\mathrm{Cr}$ HydA 1 samples to molecular oxygen could trigger the formation of $\mathrm{H}_{\text {inact }}$ or $\mathrm{H}_{\text {trans }}$, and whether these states were able to grant resistance towards $\mathrm{O}_{2}$ damage, cell suspensions were exposed to air and the effects on the H-cluster were monitored via EPR spectroscopy and enzyme activity assays. As described above, incubating cells expressing apo- $C r \mathrm{HydA} 1$ with $[2 \mathrm{Fe}]^{\text {adt }}$ for $1 \mathrm{~h}$ under anaerobic conditions, generates an enzyme population consisting of $\mathrm{H}_{\mathrm{ox}}$ and $\mathrm{H}_{\mathrm{ox}}-\mathrm{CO}$. Subsequent exposure of such samples to $\mathrm{O}_{2}$, by placing them in air for $1 \mathrm{~h}$, resulted in a noticeable decrease of the overall EPR signal intensity (total residual signal intensity $\approx 45 \%$ ) (Fig. 4, panel A). Visibly, all of the residual signal is attributable to the $\mathrm{H}_{\mathrm{ox}}-\mathrm{CO}$ state; this is expected as it is known to be more resistant to oxygen and to be formed by $\mathrm{CO}$ released upon $\mathrm{H}$-cluster degradation (a process known as "cannibalization") [27, 29]. The same air exposure treatment on samples pre-incubated under argon for $23 \mathrm{~h}$, in which the $\mathrm{H}$-cluster resides primarily in the $\mathrm{H}_{\text {trans }}$-like state, yielded a similar result, with a decrease in the intensity of the spectral features of both the $\mathrm{H}_{\text {trans }}$-like species and residual $\mathrm{H}_{\mathrm{ox}}$ (total residual signal intensity $\approx 35 \%$ ) (Fig. 4, panel B). This loss of EPR signal intensity can be attributed either to the formation of an EPR silent $\mathrm{H}_{\text {inact }}$-like state or to $\mathrm{O}_{2}$-induced degradation of the H-cluster. To separate these two possibilities, the EPR experiments were complemented with in vitro activity assays on lysed cells. The use of a strong reductant (dithionite), in combination with methyl viologen as electron mediator, is expected to re-activate any $\mathrm{H}$-cluster fraction residing in $\mathrm{H}_{\text {inact }}$ or $\mathrm{H}_{\text {trans }}$, and thus enable quantification of the entire intact $\mathrm{H}$-cluster population.

It should be noted that already prior to $\mathrm{O}_{2}$ exposure the $23 \mathrm{~h}$ pre-incubated samples did display slightly diminished activities, as compared to the $1 \mathrm{~h}$ pre-incubated samples (compare Fig. 4A and B, insets). We attribute this to H-cluster degradation, as in vitro assays show no indication of degradation processes involving the protein scaffold on a $24 \mathrm{~h}$ time scale (Fig. S4). The readily observable $\mathrm{H}_{2}$ production from the lysed cells enable a relative quantification of intact enzyme to determine the effect of $\mathrm{O}_{2}$ on the different preparations. Regardless of pre-incubation time ( 1 or $23 \mathrm{~h}$ ), the signal loss observed by EPR spectroscopy following oxygen

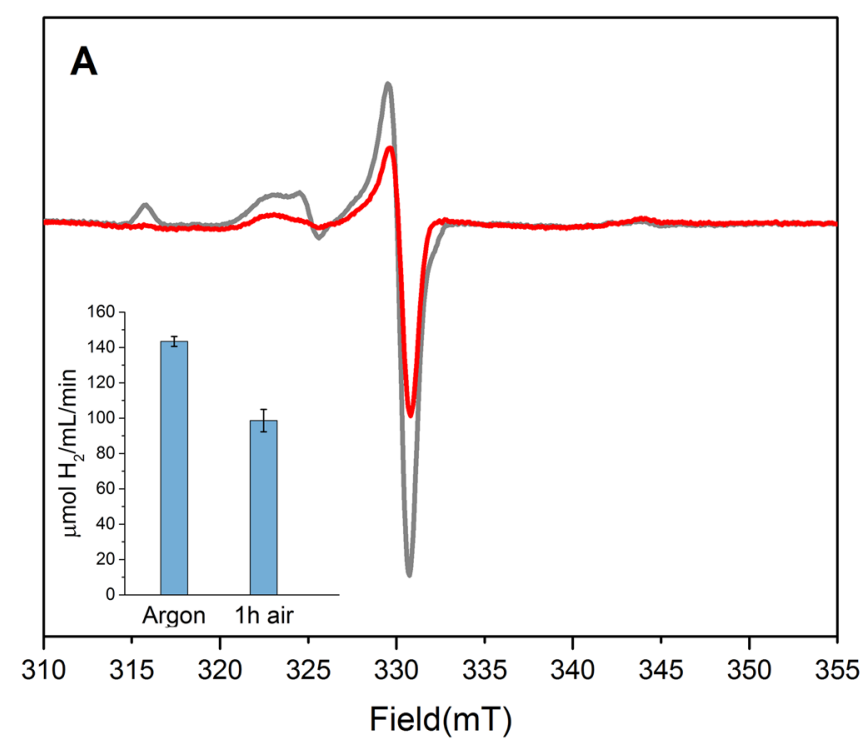

Fig. 4 Reactivity towards molecular oxygen of whole-cell $[2 \mathrm{Fe}]^{\text {adt }}-\mathrm{Cr}$ HydA1 samples. Panel A: The EPR spectrum of a wholecell $[2 \mathrm{Fe}]^{\text {adt }}-\mathrm{CrHydA} 1$ sample initially incubated for $1 \mathrm{~h}$ with $[2 \mathrm{Fe}]^{\text {adt }}$ under anaerobic conditions, and subsequently exposed to air for $1 \mathrm{~h}$ (red spectrum) is overlaid with an equivalent sample kept strictly anaerobic (gray spectrum). (Inset): Enzymatic activities for the same samples measured through in vitro assays. Panel B: The EPR spectrum of a whole-cell $[2 \mathrm{Fe}]^{\text {adt }}-\mathrm{CrHydA} 1$ sample initially incu-

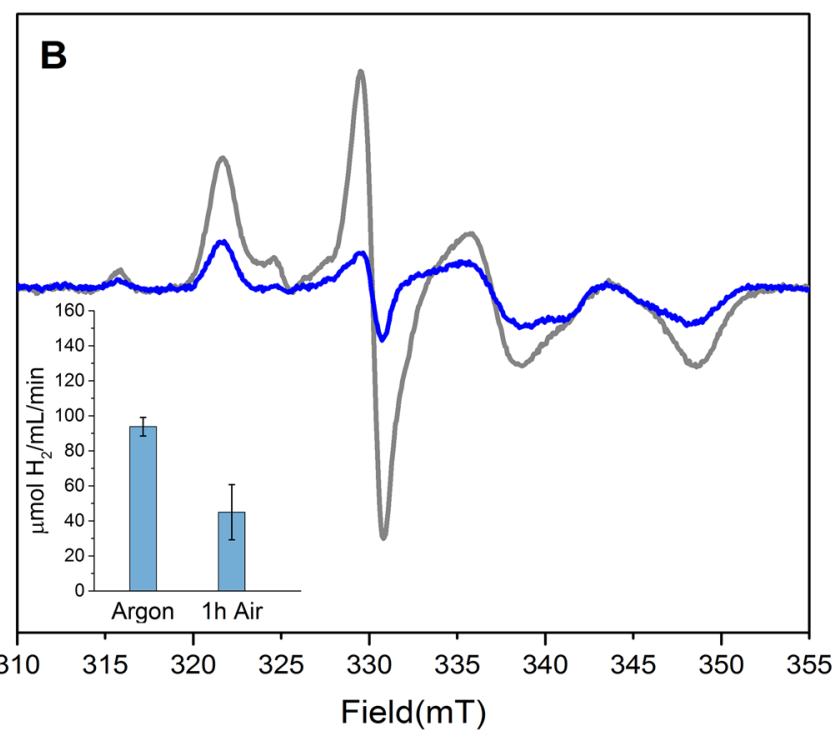

bated for $23 \mathrm{~h}$ with [2Fe] ${ }^{\text {adt }}$ under anaerobic conditions, and subsequently exposed to air for $1 \mathrm{~h}$ at ambient temperature (blue spectrum) is overlaid with an equivalent sample kept anaerobic (gray spectrum). (Inset): Enzymatic activities for the same samples measured through in vitro assays. EPR data shown come from representative spectra. Activity data represent the average values of two biological replicates with standard deviations reported as error bars. EPR experimental conditions: $\mathrm{T}=20 \mathrm{~K}, \mathrm{P}=1 \mathrm{~mW}, \nu=9.28 \mathrm{GHz}$ 
exposure was larger than the activity loss. The $1 \mathrm{~h}$-pre-incubated sample retained $\sim 70 \%$ of the $\mathrm{H}_{2}$-producing activity and the $23 \mathrm{~h}$-pre-incubated sample retained $\sim 50 \%$ of its activity, when compared to parallel samples kept under strictly anaerobic conditions (Fig. 4, insets).

Consequently, the observed EPR signal loss is attributable to a combination of $\mathrm{H}$-cluster degradation and formation of an EPR silent $\mathrm{H}_{\text {inact }}$-like state. Considering the wellestablished reactivation of $\mathrm{H}_{\text {inact }}$ under reducing conditions [29, 34], we expect the latter species to re-enter the catalytic cycle under the conditions employed in the in vitro activity assays, while the former causes a definitive loss in activity. Moreover, pre-established accumulation of the $\mathrm{H}_{\text {trans }}$-like state did not provide any apparent increase in $\mathrm{O}_{2}$-tolerance, as samples pre-incubated for $23 \mathrm{~h}$ showed larger relative activity losses as compared to samples pre-incubated only for $1 \mathrm{~h}$. In contrast, the cellular environment showed remarkable capabilities in terms of $\mathrm{O}_{2}$-protection, as a significant fraction of the $\mathrm{H}$-cluster population was not degraded nor oxidized to an $\mathrm{H}_{\text {inact }}$-like state during oxygen exposure. This is attributed to the low intracellular $\mathrm{O}_{2}$ concentrations ensured by cellular respiration, a process which is indeed expected to be more efficient in "young" and metabolically active cells [47].

\section{Structural factors influencing formation of the $\boldsymbol{H}_{\text {trans }}$ and $\mathrm{H}_{\text {inact }}$-like states}

The presence of an efficient proton-transfer chain has been proposed to be important for the formation of the $\mathrm{H}_{\text {trans }}$ and $\mathrm{H}_{\text {inact }}$ states, as the sulfide ligand is thought to enter the active-site pocket as $\mathrm{H}_{2} \mathrm{~S}$ and to undergo a proteinassisted deprotonation event to yield the $\mathrm{SH}^{-}$ligand [34]. Thus, modifications were made to both the $[2 \mathrm{Fe}]_{\mathrm{H}}$ subsite as well as to the active-site pocket to assess the importance of the proton-transfer pathway on formation of the $\mathrm{H}_{\text {trans }}$ and $\mathrm{H}_{\text {inact }}$-like states. More specifically, holo- $\mathrm{CrHydA} 1$ samples were prepared in which the $[2 \mathrm{Fe}]^{\text {adt }}$ mimic was replaced with $\left[\mathrm{Fe}_{2}(\mathrm{pdt})(\mathrm{CO})_{4}(\mathrm{CN})_{2}\right]^{2-}\left([2 \mathrm{Fe}]^{\mathrm{pdt}}, \mathrm{pdt}={ }^{-} \mathrm{SCH}_{2} \mathrm{CH}_{2} \mathrm{CH}_{2} \mathrm{~S}^{-}\right.$, propanedithiolate), generating $[2 \mathrm{Fe}]^{\mathrm{pdt}}-\mathrm{CrHydA} 1$. In this modified $\mathrm{H}$-cluster, the amine bridgehead present in the natural $[2 \mathrm{Fe}]^{\text {adt }}$ cofactor is substituted with a non-protonatable methylene group. Earlier whole-cell and in vitro spectroscopic studies, as well as crystallographic studies, have shown that $[2 \mathrm{Fe}]^{\mathrm{pdt}}-\mathrm{CrHydA} 1$ is an organometallic variant where the [2Fe] subsite is locked in an oxidized Fe(II) $\mathrm{Fe}(\mathrm{I})$ state, strikingly similar to the EPR active $\mathrm{H}_{\text {ox }}$ state of the native enzyme [14, 37-39, 43, 48, 49]. As expected, EPR samples consisting of apo- $\mathrm{CrHydA} 1$-expressing cells incubated with the $[2 \mathrm{Fe}]^{\text {pdt }}$ complex revealed the exclusive formation an $\mathrm{H}_{\mathrm{ox}}$-like species. The $\mathrm{H}$-cluster population remained locked in the $\mathrm{H}_{\mathrm{ox}}$ state for up to $23 \mathrm{~h}$ of incubation under anaerobic conditions; and no features attributable to an $\mathrm{H}_{\text {trans }}$-like species were discernable at any point during the experiment (Fig. S6).

These results seem to confirm the importance of a proton relay in the second coordination sphere of the H-cluster for the formation of the $\mathrm{H}_{\text {trans }}$ and $\mathrm{H}_{\text {inact }}$-like states. To proceed one step further down the proton-transfer pathway, the C169 residue was mutated to a serine (CrHydA1-C169S). This cysteine residue is strictly conserved in "prototypical" $[\mathrm{FeFe}]$-hydrogenases, and it is the first amino acid involved in the proton-transfer chain towards the adt-nitrogen of the H-cluster [9]. The C169S mutant has been studied extensively under in vitro conditions, and demonstrated to be a variant with a severely compromised proton-transfer pathway and significantly decreased catalytic activity [50, 51]. Incubating E. coli cells expressing $C r \mathrm{HydA} 1-\mathrm{C} 169 \mathrm{~S}$ with $[2 \mathrm{Fe}]^{\text {adt }}$ resulted in the rapid formation of a broad rhombic EPR signal with $\mathrm{g}_{\mathrm{zyx}}=2.064 ; 1.970 ; 1.910$, very closely matching the $\mathrm{H}_{\text {trans }}$-like signal in the wild-type enzyme $\left(\mathrm{g}_{\mathrm{zyx}}=2.064 ; 1.972 ; 1.910\right)$. A signal with comparable EPR properties has been reported from in vitro studies of the C169S mutant $\left(\mathrm{g}_{\mathrm{zyx}}=2.065 ; 1.969 ; 1.906\right)$ [51, 52]. It was originally assigned to an $\mathrm{H}_{\text {trans }}$-like species, potentially featuring a hydride ligand. However, despite the similarity in $\mathrm{g}$ values the signal observed under our in vivo conditions is highly unlikely to represent a metal hydride species. No other $\mathrm{H}$-cluster derived features were discernable in the EPR spectrum (Fig. 5).

The evolution of this $\mathrm{H}_{\text {trans }}$-like signal over time was examined with long-term ( $1 \mathrm{~h}, 3 \mathrm{~h}, 23 \mathrm{~h}, 48 \mathrm{~h})$ incubation of the cells with the $[2 \mathrm{Fe}]^{\text {adt }}$ cofactor, and no significant change was detected neither in the shape, nor intensity of the signal (Fig. 5). The stability of this state was further confirmed by its isolation. In contrast to the wild-type protein, [2Fe] $]^{\text {adt }}-\mathrm{Cr}$ HydA1-C169S could be purified in its $\mathrm{H}_{\text {trans }}$-like state via affinity chromatography following anaerobic cell lysis. However, this required supplementing the buffers with $100 \mathrm{mM} \mathrm{Na} 2 \mathrm{~S}$, as omitting sulfide resulted in a complete loss of the $\mathrm{H}_{\text {trans }}$-like rhombic EPR signal (Fig. S7). Albeit EPR spectroscopy revealed rapid $\mathrm{H}$-cluster formation, no in vivo or in vitro hydrogen production could be detected from $[2 \mathrm{Fe}]^{\text {adt }}-\mathrm{Cr} \mathrm{HydA} 1-\mathrm{C} 169 \mathrm{~S}$ samples, as expected from this reportedly inactive variant [50].

To gain more insight into potential intermediates formed on route to the $\mathrm{H}_{\text {trans }}$-like state in the C169S mutant, the process was studied at lower temperature. More specifically, apo- $\mathrm{CrHydA1-C169S}$ containing cells were treated with $[2 \mathrm{Fe}]^{\text {adt }}$ at $12{ }^{\circ} \mathrm{C}$. The first discernable state generated under these conditions was $\mathrm{H}_{\text {ox }}(20-60 \mathrm{~min})$, while the $\mathrm{H}_{\text {trans }}$-like state only started to be detectable after $2 \mathrm{~h}$ of incubation with $[2 \mathrm{Fe}]^{\text {adt }}$ (Fig. S8). The $\mathrm{H}_{\text {trans }}$-like signal reached full intensity after overnight incubation with the cofactor.

As modifications of the bridgehead atom showed clearly diverging effects as compared to the C169S mutant, with 


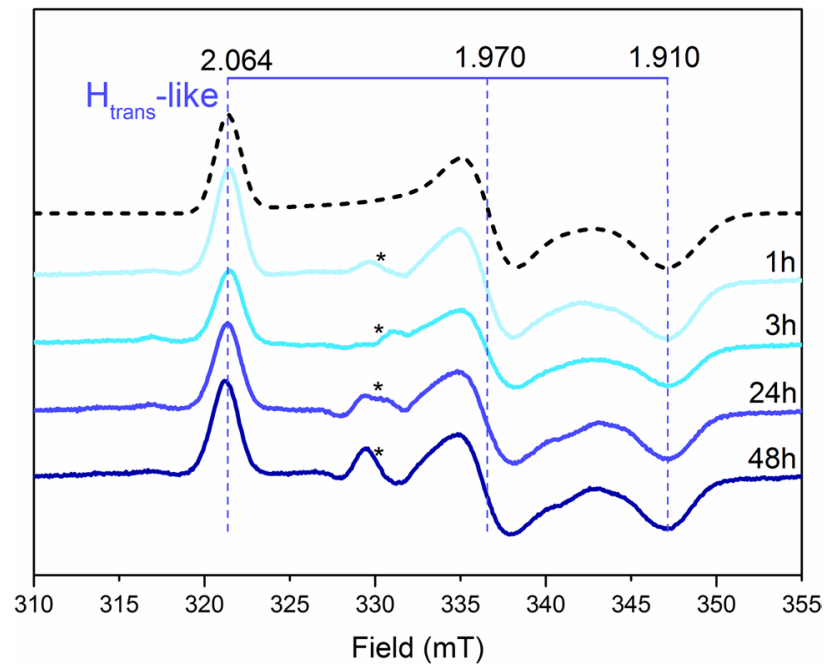

Fig. 5 Monitoring the formation of the $\mathrm{H}_{\text {trans }}$-like state in $[2 \mathrm{Fe}]^{\text {adt }}-\mathrm{CrHydA} 1-\mathrm{C} 169 \mathrm{~S}$ under whole-cell conditions by EPR spectroscopy. EPR spectra recorded for $E$. coli cells expressing apoCrHydA1-C169S flash frozen after incubation with $[2 \mathrm{Fe}]^{\text {adt }}$ for 1,3 , 24 or $48 \mathrm{~h}$ at $37^{\circ} \mathrm{C}$. A characteristic $\mathrm{H}_{\text {trans }}$-like signature became visible already after $1 \mathrm{~h}$ of incubation; a spectral simulation for this species is shown as a stacked dashed line and $g$ values obtained from the fittings are reported. Unassigned, sample-specific weak signals potentially arising from the imperfect subtraction of the cell background are indicated with asterisks. EPR experimental conditions: $\mathrm{T}=20 \mathrm{~K}$, $\mathrm{P}=1 \mathrm{~mW}, \nu=9.28 \mathrm{GHz}$

regards to formation of the $\mathrm{H}_{\text {trans }}$-like state, the combined effect of the latter mutation and the methylene-bridgehead mimic was investigated. Whole-cell samples of the C169S mutant matured with $[2 \mathrm{Fe}]^{\mathrm{pdt}}\left([2 \mathrm{Fe}]^{\mathrm{pdt}}-\mathrm{CrHydA} 1-\mathrm{C} 169 \mathrm{~S}\right)$ initially displayed a behavior consistent with the $[2 \mathrm{Fe}]^{\mathrm{pdt}}$ wild-type, with an EPR spectrum showing an $\mathrm{H}$-cluster apparently locked in an $\mathrm{H}_{\mathrm{ox}}$ - like state (Fig. 6). However, a signal corresponding to an $\mathrm{H}_{\text {trans }}$-like state started to accumulate after $3 \mathrm{~h}$ of incubation and became predominant after $24 \mathrm{~h}$. No other signals arose thereafter, on a time scale of days ( $96 \mathrm{~h})$.

In summary, the $[2 \mathrm{Fe}]^{\mathrm{pdt}}$-variant of the wild-type CrHydA1 does not form detectable amounts of any $\mathrm{H}_{\text {trans }}$ or $\mathrm{H}_{\text {inact }}$-like states, in agreement with previous studies performed in vitro [34]. Conversely, the [2Fe] $]^{\text {pdt }}$ CrHydA1-C169S 'double' variant showed accumulation of the $\mathrm{H}_{\text {trans }}$-like state. This shows that the presence of a nitrogen-bridgehead facilitates, but is not critical, for the formation of these inhibited states. Rather, it underscores that additional factors in the outer coordination sphere also affect their formation. These include a decrease of steric bulk resulting from the replacement of a thiol group with an alcohol that provides easier access for exogenous ligands and a change in the hydrogen-bonding dynamics involving the first and second coordination spheres.

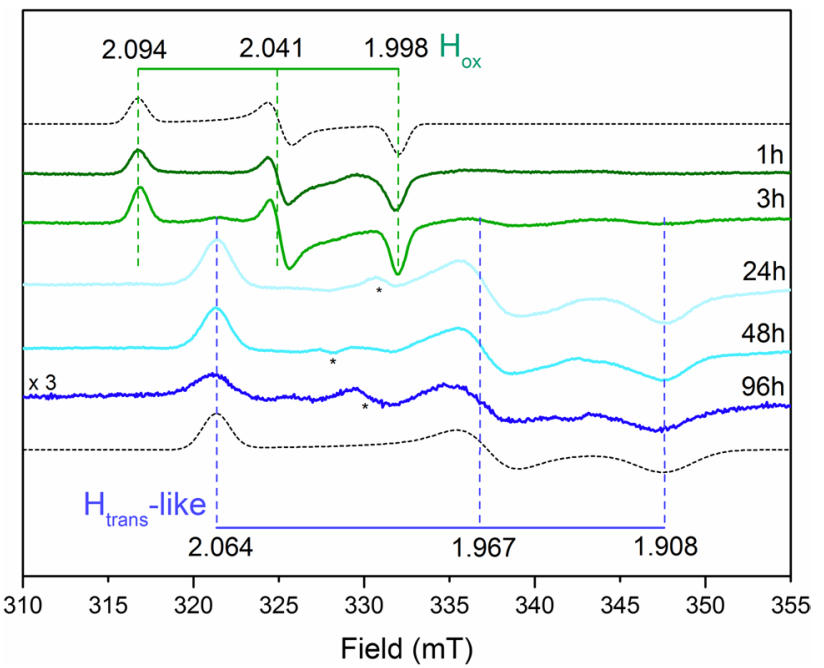

Fig. 6 Monitoring the formation of the $\mathrm{H}_{\text {trans }}$-like state in $\mathrm{CrHydA1-}$ C169S with the $[2 \mathrm{Fe}]^{\mathrm{pdt}}$ cofactor. EPR spectra of $E$. coli cells expressing apo-CrHydA1-C169S after incubation with $[2 \mathrm{Fe}]^{\mathrm{pdt}}$ for variable amounts of time at $37{ }^{\circ} \mathrm{C}$. The $\mathrm{H}_{\text {trans }}$-like signature only became visible after $23 \mathrm{~h}$ of incubation. Unassigned, sample-specific weak signals potentially arising from the imperfect subtraction of the cell background are indicated with asterisks. EPR experimental conditions: $\mathrm{T}=20 \mathrm{~K}, \mathrm{P}=1 \mathrm{~mW}, \nu=9.28 \mathrm{GHz}$

\section{Conclusions}

Semi-synthetic [FeFe]-hydrogenases have been shown to remain catalytically active in cyanobacteria on a time scale of days [43, 53]. The observation that $E$. coli cells expressing C. reinhardtii $[\mathrm{FeFe}]$-hydrogenase can produce hydrogen gas only transiently following enzyme activation has raised the question on the stability of these enzymes in the bacterial cytoplasm.

In the case of $C r$ HydA1, EPR spectra recorded on long time-scale samples show the gradual accumulation of an $\mathrm{H}_{\text {trans }}$-like state under the slow-turnover conditions assayed here. However, the rate of formation of this $\mathrm{H}_{\text {trans }}$-like state clearly varies between $[\mathrm{FeFe}]$-hydrogenases, as $D d \mathrm{HydAB}$ did not form a similar state under identical experimental conditions. The latter observation is tentatively attributed to $D d$ HydAB's high affinity for CO, resulting in a relatively stable $\mathrm{H}_{\text {ox }}-\mathrm{CO}$ population unable to convert to the $\mathrm{H}_{\text {trans }}$-like state under the conditions employed here.

In light of its stability, we propose that the observed $\mathrm{H}_{\text {trans }}$-like state represents a thermodynamic sink for the enzyme accessed under the whole-cell conditions employed here. Moreover, its formation is evidently accelerated by mutating amino-acid residues close to the open-coordination site of the cofactor, and by the presence of an aminogroup in the bridging dithiolate ligand. Models have been proposed that focus on the role of the hydrogen-bonding network in stabilizing apical ligands, therefore, it can be 
hypothesized that the nature of the $\mathrm{H}$-bond partners in the vicinity of the apical site can significantly influence the formation of an inhibited state. [54] In addition, a cysteineto-serine mutation has the effect of reducing the steric hindrance close to the open-coordination site of the cofactor, which could further facilitate the insertion of an inhibitor ligand. The positive effect of adding sulfide for generating this species and stabilizing it, as during isolation of $[2 \mathrm{Fe}]^{\text {adt }}-\mathrm{Cr}$ HydA1-C169S, suggests that the observed rhombic EPR signal can be attributed to the in vitro characterized $\mathrm{H}_{\text {trans }}$ state. The observation of $\mathrm{H}_{\text {trans }}$ under whole-cell conditions would support a physiological relevance of this state. However, we note that the in vivo data does not unequivocally prove the structure of this species, and further investigations on the nature of this $\mathrm{H}_{\text {trans }}$-like state are underway.

Albeit the $\mathrm{H}_{\text {trans }}$-like state appears stable, it does not seem to offer substantial protection against oxygen damage, in contrast to in vitro observations $[33,34]$. Conversely, $E$. coli cells were found to provide a surprisingly high level of protection versus air, highlighting the potential of $E$. coli as a suitable host organism for oxygen-sensitive enzymes in bio (hybrid) technological applications.

In closing, the spontaneous formation of inactive species could pose a problem in the development of systems that take advantage of bacterial hosts to develop whole-cell hydrogen production systems, as it potentially shortens their service life. Having discovered the critical role of the steric occupancy and the hydrogen-bonding network of the activesite pocket in regulating the kinetics of this phenomenon, a possible path for research could be to fine-tune these parameters and thus develop potentially more robust catalysts.

\section{Experimental procedures}

General. All chemicals were purchased from Sigma-Aldrich or VWR and used as received unless otherwise stated. All anaerobic work was performed in an MBRAUN glovebox $\left(\left[\mathrm{O}_{2}\right]<10 \mathrm{ppm}\right)$. The expression vector encoding the hydAl gene (pETDuet-CrHydA1-His) was kindly provided by Prof. Marc Fontecave (College de France, Paris/CEA, Grenoble). $\left.\left(\mathrm{Et}_{4} \mathrm{~N}\right)_{2}\left[\mathrm{Fe}_{2}(\mathrm{adt})(\mathrm{CO})_{4}(\mathrm{CN})_{2}\right]\left([2 \mathrm{Fe}]^{\text {adt }}\right]\right)$ and $\left.\left(\mathrm{Et}_{4} \mathrm{~N}\right)_{2}\left[\mathrm{Fe}_{2}(\mathrm{pdt})(\mathrm{CO})_{4}(\mathrm{CN})_{2}\right]\left([2 \mathrm{Fe}]^{\mathrm{pdt}}\right]\right)$ were synthesized in accordance to literature protocols with minor modifications, and verified by FTIR spectroscopy [55-58]. The complexes were dissolved in anaerobic potassium phosphate buffer $(100 \mathrm{mM}, \mathrm{pH} 6.8)$ at $10 \mu \mathrm{g} / \mu \mathrm{L}$ concentration and used directly. Protein content was analyzed by $10 \%$ SDS-PAGE minigels in a BioRad Mini-PROTEAN Tetra Cell system. Protein bands were stained with Page Blue protein staining solution (Thermo Fisher Scientific) according to the supplier`s instructions.
Generation of CrHydA1-C169S mutant. To generate the $\mathrm{C} 169 \mathrm{~S}$ mutant in HydA1 protein, the triplet coding for the cysteine amino acid in position 169 (TGC) was replaced with one coding for serine (TCC). The pETDuet-CrHydA1His was mutated with the Quick Change Site-Directed Mutagenesis Kit (Agilent) according to the manufacturer instructions using 5 GTTTACCAGCTCCTGCCCGGG CTGGATTGC' $3{ }^{\prime}$ and 5 ' GCAATCCAGCCCGGGCAG GAGCTGGTAAAC 3 ` primers. The amino-acid change was verified by sequencing.

Overexpression of the apo- $\mathrm{CrHydA1}$ hydrogenase. Escherichia coli BL21(DE3) cells containing the $C r \mathrm{HydA} 1$ plasmid were grown in $50 \mathrm{~mL}$ M9 medium $[22 \mathrm{mM}$ $\mathrm{Na}_{2} \mathrm{HPO}_{4}, 22 \mathrm{mM} \mathrm{KH}_{2} \mathrm{PO}_{4}, 85 \mathrm{mM} \mathrm{NaCl}, 18 \mathrm{mM} \mathrm{NH}_{4} \mathrm{Cl}$, $0.2 \mathrm{mM} \mathrm{MgSO}_{4}, 0.1 \mathrm{mM} \mathrm{CaCl}_{2}, 0.4 \%$ (v/v) glucose] under aerobic conditions until O.D. ${ }_{600}=0.6-0.8$ in the presence of ampicillin. The protein overproduction was induced with $1 \mathrm{mM}$ IPTG and persisted at $20^{\circ} \mathrm{C}$ for $16-18 \mathrm{~h}$ with continuous aeration. The media was supplemented with $100 \mu \mathrm{M}$ $\mathrm{FeSO}_{4}$ at the time of the induction. Final O.D. ${ }_{600}$ of the cultures were $1.4 \pm 0.2$.

Overexpression of the apo-DdHydAB hydrogenase. Escherichia coli BL21(DE3) cells containing the pACYCDuet- $D d$ HydAB plasmid[44] were grown in $50 \mathrm{~mL}$ M9 medium [ $22 \mathrm{mM} \mathrm{Na}_{2} \mathrm{HPO}_{4}, 22 \mathrm{mM} \mathrm{KH} \mathrm{PO}_{4}, 85 \mathrm{mM} \mathrm{NaCl}$, $18 \mathrm{mM} \mathrm{NH}_{4} \mathrm{Cl}, 0.2 \mathrm{mM} \mathrm{MgSO}_{4}, 0.1 \mathrm{mM} \mathrm{CaCl}_{2}$ ], supplemented with $0.4 \%(\mathrm{w} / \mathrm{v})$ glucose, under aerobic conditions until O.D. ${ }_{600}=0.6-0.8$ in the presence of chloramphenicol. The protein overproduction was induced with $1 \mathrm{mM}$ IPTG and persisted at $20{ }^{\circ} \mathrm{C}$ for $16-18 \mathrm{~h}$ with continuous aeration. The media was supplemented with $400 \mu \mathrm{M} \mathrm{FeSO}_{4}$ at the time of the induction. Final O.D. ${ }_{600}$ of the cultures were $1.4 \pm 0.2$.

In vivo formation of $[2 \mathrm{Fe}]^{\text {adt }}-\mathrm{CrHydA1},[2 \mathrm{Fe}]^{\text {pdt }}$ CrHydA1, [2Fe] ${ }^{\text {adt }}-D d H y d A B$ and $[2 \mathrm{Fe}]^{\text {pdt }}-D d \mathrm{HydAB}$. The preparation of the semi-synthetic hydrogenase was performed following literature protocols with minor modifications $[38,39]$. The apo-protein was expressed in $50 \mathrm{~mL}$ E. coli cultures as described in the "Overexpression of the apo-CrHydAl hydrogenase" and "Overexpression of the apo-DdHydAB hydrogenase" sections. After the 16-18 h expression period the cells were harvested, deaerated and transferred to the glovebox. The cells were re-suspended in fresh M9 medium ( $2 \mathrm{~mL}$ final volume), and formation of $[2 \mathrm{Fe}]^{\text {adt }}-C r \mathrm{HydA} 1,[2 \mathrm{Fe}]^{\mathrm{pdt}}-C r \mathrm{HydA} 1,[2 \mathrm{Fe}]^{\text {adt }}-D d \mathrm{HydAB}$ and $[2 \mathrm{Fe}]^{\mathrm{pdt}}-D d \mathrm{HydAB}$ was achieved by incubating the cell suspensions with $100 \mu \mathrm{g}(156 \mathrm{nmol})[2 \mathrm{Fe}]^{\text {adt }}$ or $100 \mu \mathrm{g}$ $(156 \mathrm{nmol})[2 \mathrm{Fe}]^{\mathrm{pdt}}$ complex $(80 \mu \mathrm{M}$ final conc.), for 1 $-96 \mathrm{~h}$ at $37^{\circ} \mathrm{C}$ under strictly anaerobic conditions. When indicated, the medium was supplemented with $375 \mu \mathrm{M}$ L-cysteine or $375 \mu \mathrm{M} \mathrm{Na} 2 \mathrm{~S}$.

For the medium exchange experiments, after $23 \mathrm{~h}$ incubation the cell suspensions were transferred in the 
glovebox, centrifuged and the resulting pellet was resuspended in fresh M9 media, supplemented with $0.4 \%$ (w/v) glucose when necessary. The cell suspensions were then incubated for $2 \mathrm{~h}$ at $37{ }^{\circ} \mathrm{C}$ under strictly anaerobic conditions.

Whole-cell EPR sample preparation. The $2 \mathrm{~mL}$ concentrated cell suspensions generated via the "In vivo formation of $[2 \mathrm{Fe}]^{\text {adt }}-\mathrm{HydAI},[2 \mathrm{Fe}]^{p d t}-\mathrm{HydAl},[2 \mathrm{Fe}]^{\text {adt }}-\mathrm{DdHydAB}$ and $[2 \mathrm{Fe}]^{p d t}$-DdHydAB" protocol were centrifuged and the cell pellet washed with $1 \mathrm{~mL}$ TRIS-HCl buffer (100 mM TRIS, $150 \mathrm{mM} \mathrm{NaCl} \mathrm{pH} 7.5$ ) three times under anaerobic conditions. After washing, the cells were diluted to a final volume of $400 \mu \mathrm{L}$ using the same buffer and transferred into EPR tubes. The tubes were capped and directly frozen in liquid nitrogen.

Isolation of [2Fe] ${ }^{\text {adt }}$-CrHydA1-C169S. $100 \mathrm{~mL}$ of C169S-CrHydA1 cells were activated with $100 \mu \mathrm{g}[2 \mathrm{Fe}]^{\text {adt }}$ for $1 \mathrm{~h}$. After activation the cells were lysed in lysis buffer (50 mM sodium phosphate buffer $\mathrm{pH} 7.8,100 \mathrm{mM} \mathrm{NaCl}$,

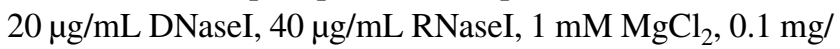
$\mathrm{mL}$ lysozyme) using three freeze-thaw cycles. The soluble fraction of the cell lysate was separated with 13,000 rpm centrifugation for $20 \mathrm{~min}$ under anaerobic conditions. The protein was purified using a $1 \mathrm{~mL}$ Ni-sepharose High Performance (GE Heathcare) gravity column equilibrated with 10 column volumes of equilibration buffer $(50 \mathrm{mM}$ sodium phosphate buffer $\mathrm{pH} 7.8,100 \mathrm{mM} \mathrm{NaCl}$ ) in the glovebox. The non-specifically bound proteins were removed with wash buffer $(50 \mathrm{mM}$ sodium phosphate buffer $\mathrm{pH} 7.8$, $100 \mathrm{mM} \mathrm{NaCl}, 20 \mathrm{mM}$ imidazole). The [2Fe]-C169S$\mathrm{CrHydA} 1$ protein was eluted with $1.5 \mathrm{~mL}$ elution buffer (50 mM sodium phosphate buffer $\mathrm{pH} 7.8,100 \mathrm{mM} \mathrm{NaCl}$, $300 \mathrm{mM}$ imidazole), the elution fraction was directly used for EPR samples. The purity of the purified protein was confirmed with SDS-PAGE.

Hydrogenase activity measurements. Activity measurements were performed on whole-cell samples as well as under in vitro conditions using published protocols [39]. Selected technical details are re-iterated for clarity. Wholecell activities were determined from cell suspensions $(2 \mathrm{~mL}$ final volume), incubated in gastight vials with a total volume of $9 \mathrm{~mL}$. In vitro assays were performed on cell lysates. The reaction mix contained potassium phospate buffer (pH 6.8, $100 \mathrm{mM}$ ), Triton-X 1.5\% v/v and methyl viologen $(14 \mathrm{mM})$; the reaction was initiated with the addition of dithionite $(200 \mathrm{mM})$ and the sample vials incubated for $15 \mathrm{~min}$ at $37{ }^{\circ} \mathrm{C}$ prior to headspace sampling. Hydrogen production was determined by analyzing the headspace gas, using a gas chromatograph (GC; PerkinElmer LLC, MA, USA) equipped with a thermal conductivity detector (TCD) and a stainless-steel column packed with Molecular Sieve (60/80 mesh). A calibration curve was established by injecting known amounts of hydrogen. The operational temperatures of the injection port, the oven and the detector were $100^{\circ} \mathrm{C}$, $80^{\circ} \mathrm{C}$ and $100{ }^{\circ} \mathrm{C}$, respectively. Argon was used as the car-

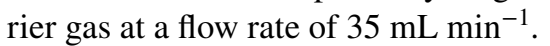

EPR measurements. The EPR spectra shown are representative signals from at least two individual experiments. The individual experiments show some preparation dependent differences, but the amplitude of these background signals are negligible compared to the signal intensity of the $[2 \mathrm{Fe}]^{\text {adt }}$ activated $\mathrm{CrHydA} 1$. Measurements were performed on a Bruker ELEXYS E500 spectrometer using an ER049X SuperX microwave bridge in a Bruker SHQ0601 cavity equipped with an Oxford Instruments continuous flow cryostat and using an ITC 503 temperature controller (Oxford Instruments). Measurement temperatures ranged from 10 to $20 \mathrm{~K}$, using liquid helium as coolant, with the following EPR settings unless otherwise stated: microwave power $1 \mathrm{~mW}$, modulation amplitude $1 \mathrm{mT}$, modulation frequency $100 \mathrm{kHz}$. The spectrometer was controlled by the Xepr software package (Bruker).

EPR spectra processing and simulations. The EPR spectra were processed using the softwares Matlab (Mathworks, Inc) and QSoas [59]. Matlab served for converting the EPR files to ascii format, while QSoas was used to display the spectra as a function of $g$ values, for visual inspection and subtraction of background signals emerging from the cells. The processed signals were used for Figs. 2, 3, 4, $5,6, \mathrm{~S} 2$ and S3, S5 to S8. The simulations were performed using the Easyspin toolbox (5.2.23) within Matlab [60]. Other details of the procedure can be found in [38].

Supplementary Information The online version contains supplementary material available at https://doi.org/10.1007/s00775-022-01928-5.

Acknowledgements The Horizon 2020 program, European Research Council Starting Grant, ERC StG (G. B. contract number 714102) and Horizon 2020 program, Innovative Training Network, ITN (G. B., eSCALED, contract number 765376) are gratefully acknowledged for funding. P.R.-M. and J.A.B. wish to thank the Max Planck Society for funding. Additionally, J.A.B. acknowledges funding from the Deutsche Forschungsgemeinschaft, DFG SPP1927 "Iron-Sulfur for Life: Cooperative Function of Iron-Sulfur Centers in Assembly, Biosynthesis, Catalysis, and Disease", Project BI 2198/1-1. P.R.-M. is supported financially by the European Research Council (ERC-2018-CoG BiocatSusChem 819580, to K.A. Vincent), and acknowledges Linacre College Oxford for her Junior Research Fellowship.

Funding Open access funding provided by Uppsala University.

\section{Declarations}

Conflict of interest The authors have no competing interests to declare that are relevant to the content of this article.

Open Access This article is licensed under a Creative Commons Attribution 4.0 International License, which permits use, sharing, adaptation, distribution and reproduction in any medium or format, as long as you give appropriate credit to the original author(s) and the source, 
provide a link to the Creative Commons licence, and indicate if changes were made. The images or other third party material in this article are included in the article's Creative Commons licence, unless indicated otherwise in a credit line to the material. If material is not included in the article's Creative Commons licence and your intended use is not permitted by statutory regulation or exceeds the permitted use, you will need to obtain permission directly from the copyright holder. To view a copy of this licence, visit http://creativecommons.org/licenses/by/4.0/.

\section{References}

1. Madden C, Vaughn MD, Díez-Pérez I, Brown KA, King PW, Gust D, Moore AL, Moore TA (2012) J Am Chem Soc 134:1577-1582

2. Lubitz W, Ogata H, Rudiger O, Reijerse E (2014) Chem Rev 114:4081-4148

3. Hambourger M, Gervaldo M, Svedruzic D, King PW, Gust D, Ghirardi M, Moore AL, Moore TA (2008) J Am Chem Soc 130:2015-2022

4. Krishnan S, Armstrong FA (2012) Chem Sci 3:1015-1023

5. Plumeré N, Rüdiger O, Oughli AA, Williams R, Vivekananthan J, Pöller S, Schuhmann W, Lubitz W (2014) Nat Chem 6:822-827

6. Abe JO, Popoola API, Ajenifuja E, Popoola OM (2019) Int J Hydrogen Energy 44:15072-15086

7. Benoit SL, Maier RJ, Sawers RG, Greening C (2020) Microbiol Mol Biol Rev 84:e00092-e119

8. Esmieu C, Raleiras P, Berggren G (2018) Sustain Energy Fuels 2:724-750

9. Land H, Senger M, Berggren G, Stripp ST (2020) ACS Catal 10:7069-7086

10. Nangle SN, Sakimoto KK, Silver PA, Nocera DG (2017) Curr Opin Chem Biol 41:107-113

11. Simmons TR, Berggren G, Bacchi M, Fontecave M, Artero V (2014) Coord Chem Rev 270-271:127-150

12. Nicolet Y, Piras C, Legrand P, Hatchikian CE, Fontecilla-Camps JC (1999) Structure 7:13-23

13. Silakov A, Kamp C, Reijerse E, Happe T, Lubitz W (2009) Biochemistry 48:7780-7786

14. Berggren G, Adamska A, Lambertz C, Simmons TR, Esselborn J, Atta M, Gambarelli S, Mouesca JM, Reijerse E, Lubitz W, Happe T, Artero V, Fontecave M (2013) Nature 499:66-69

15. Peters JW, Lanzilotta WN, Lemon BJ, Seefeldt LC (1998) Science 282:1853-1858

16. Stripp ST, Goldet G, Brandmayr C, Sanganas O, Vincent KA, Haumann M, Armstrong FA, Happe T (2009) Proc Natl Acad Sci USA 106:17331-17336

17. Caserta G, Papini C, Adamska-Venkatesh A, Pecqueur L, Sommer C, Reijerse E, Lubitz W, Gauquelin C, Meynial-Salles I, Pramanik D, Artero V, Atta M, del Barrio M, Faivre B, Fourmond V, Léger C, Fontecave M (2018) J Am Chem Soc 140:5516-5526

18. Kubas A, Orain C, De Sancho D, Saujet L, Sensi M, Gauquelin C, Meynial-Salles I, Soucaille P, Bottin H, Baffert C, Fourmond V, Best RB, Blumberger J, Léger C (2017) Nat Chem 9:88-95

19. Morra S, Arizzi M, Valetti F, Gilardi G (2016) Biochemistry 55:5897-5900

20. Swanson KD, Ratzloff MW, Mulder DW, Artz JH, Ghose S, Hoffman A, White S, Zadvornyy OA, Broderick JB, Bothner B, King PW, Peters JW (2015) J Am Chem Soc 137:1809-1816

21. Esselborn J, Kertess L, Apfel U-P, Hofmann E, Happe T (2019) J Am Chem Soc 141:17721-17728

22. van der Westen HM, Mayhew SG, Veeger C (1978) FEBS Lett $86: 122-126$

23. Stiebritz MT, Reiher M (2012) Chem Sci 3:1739-1751

24. Glick BR, Martin WG, Martin SM (1980) Can J Microbiol 26:1214-1223
25. Patil DS, Moura JJ, He SH, Teixeira M, Prickril BC, DerVartanian DV, Peck HD, LeGall J, Huynh BH (1988) J Biol Chem 263:18732-18738

26. Kubas A, De Sancho D, Best RB, Blumberger J (2014) Angew Chem Int Ed 53:4081-4084

27. Albracht SPJ, Roseboom W, Hatchikian EC (2006) J Biol Inorg Chem 11:88-101

28. Pierik AJ, Hagen WR, Redeker JS, Wolbert RBG, Boersma M, Verhagen MFJM, Grande HJ, Veeger C, Mutsaers PHA, Sands RH, Dunham WR (1992) Eur J Biochem 209:63-72

29. Roseboom W, De Lacey AL, Fernandez VM, Hatchikian EC, Albracht SPJ (2006) J Biol Inorg Chem 11:102-118

30. Patil DS, He SH, Der Vartanian DV, Le Gall J, Huynh BH, Peck HD (1988) FEBS Lett 228:85-88

31. Kamp C, Silakov A, Winkler M, Reijerse EJ, Lubitz W, Happe T (2008) Biochim Biophys Acta. Bioenerg 1777:410-416

32. Bennett B, Lemon BJ, Peters JW (2000) Biochemistry 39:7455-7460

33. Rodríguez-Maciá P, Galle LM, Bjornsson R, Lorent C, Zebger I, Yoda Y, Cramer SP, DeBeer S, Span I, Birrell JA (2020) Angew Chem Int Ed 59:16786-16794

34. Rodríguez-Maciá P, Reijerse EJ, van Gastel M, DeBeer S, Lubitz W, Rüdiger O, Birrell JA (2018) J Am Chem Soc 140:9346-9350

35. Corrigan PS, Tirsch JL, Silakov A (2020) J Am Chem Soc 142:12409-12419

36. Mészáros LS, Ceccaldi P, Lorenzi M, Redman HJ, Pfitzner E, Heberle J, Senger M, Stripp ST, Berggren G (2020) Chem Sci 11:4608-4617

37. Land H, Ceccaldi P, Mészáros LS, Lorenzi M, Redman HJ, Senger M, Stripp ST, Berggren G (2019) Chem Sci 10:9941-9948

38. Meszaros LS, Nemeth B, Esmieu C, Ceccaldi P, Berggren G (2018) Angew Chem Int Ed 57:2596-2599

39. Khanna N, Esmieu C, Mészáros LS, Lindblad P, Berggren G (2017) Energy Environ Sci 10:1563-1567

40. Posewitz MC, King PW, Smolinski SL, Zhang L, Seibert M, Ghirardi ML (2004) J Biol Chem 279:25711-25720

41. Mulder DW, Ortillo DO, Gardenghi DJ, Naumov AV, Ruebush SS, Szilagyi RK, Huynh B, Broderick JB, Peters JW (2009) Biochemistry 48:6240-6248

42. Mulder DW, Boyd ES, Sarma R, Lange RK, Endrizzi JA, Broderick JB, Peters JW (2010) Nature 465:248-251

43. Wegelius A, Khanna N, Esmieu C, Barone GD, Pinto F, Tamagnini P, Berggren G, Lindblad P (2018) Energy Environ Sci 11:3163-3167

44. Birrell JA, Wrede K, Pawlak K, Rodriguez-Maciá P, Rüdiger O, Reijerse EJ, Lubitz W (2016) Isr J Chem 56:852-863

45. Rodríguez-Maciá P, Pawlak K, Rüdiger O, Reijerse EJ, Lubitz W, Birrell JA (2017) J Am Chem Soc 139:15122-15134

46. Goldet G, Brandmayr C, Stripp ST, Happe T, Cavazza C, FontecillaCamps JC, Armstrong FA (2009) J Am Chem Soc 131:14979-14989

47. Lempp M, Lubrano P, Bange G, Link H (2020) Biol Chem 401:1479-1485

48. Adamska-Venkatesh A, Krawietz D, Siebel J, Weber K, Happe T, Reijerse E, Lubitz W (2014) J Am Chem Soc 136:11339-11346

49. Esselborn J, Lambertz C, Adamska-Venkatesh A, Simmons T, Berggren G, Noth J, Siebel J, Hemschemeier A, Artero V, Reijerse E, Fontecave M, Lubitz W, Happe T (2013) Nat Chem Biol 9:607-609

50. Knörzer P, Silakov A, Foster CE, Armstrong FA, Lubitz W, Happe T (2012) J Biol Chem 287:1489-1499

51. Mulder DW, Guo Y, Ratzloff MW, King PW (2017) J Am Chem Soc 139:83-86

52. Mulder DW, Ratzloff MW, Bruschi M, Greco C, Koonce E, Peters JW, King PW (2014) J Am Chem Soc 136:15394-15402

53. Wegelius A, Land H, Berggren G, Lindblad P (2021) Cell Rep Phys Sci 2:100376

54. Duan J, Mebs S, Laun K, Wittkamp F, Heberle J, Happe T, Hofmann E, Apfel U-P, Winkler M, Senger M, Haumann M, Stripp ST (2019) ACS Catal 9:9140-9149 
55. Le Cloirec A, Davies SC, Evans DJ, Hughes DL, Pickett CJ, Best SP, Borg S (1999) ChemComm 22:2285-2286

56. Lyon EJ, Georgakaki IP, Reibenspies JH, Darensbourg MY (1999) Angew Chem Int Ed 38:3178-3180

57. Schmidt M, Contakes SM, Rauchfuss TB (1999) J Am Chem Soc 121:9736-9737

58. Li H, Rauchfuss TB (2002) J Am Chem Soc 124:726-727

59. Fourmond V (2016) Anal Chem 88:5050-5052
60. Stoll S, Schweiger A (2006) J Magn Reson 178:42-55

Publisher's Note Springer Nature remains neutral with regard to jurisdictional claims in published maps and institutional affiliations.

\section{Authors and Affiliations}

\section{Marco Lorenzi ${ }^{1} \cdot$ Pierre Ceccaldi ${ }^{1,2} \cdot$ Patricia Rodríguez-Maciá ${ }^{3,4} \cdot$ Holly Jayne Redman ${ }^{1} \cdot$ Afridi Zamader $^{1,5}$. James A. Birrell ${ }^{3}$ - Livia S. Mészáros ${ }^{1} \cdot$ Gustav Berggren $^{1}$ (D)}

Livia S. Mészáros

Livia.Meszaros@kemi.uu.se

1 Molecular Biomimetics, Department of ChemistryÅngström Laboratory, Uppsala University, Box 523, 75120 Uppsala, Sweden

2 Present Address: Current Address: R\&I Consultant, Home Office, Marseille, France

3 Department of Inorganic Spectroscopy, Max Planck Institute for Chemical Energy Conversion, Stiftstrasse 34-36, 45470 Mülheim an der Ruhr, Germany
4 Present Address: Current address: Department of Chemistry, Inorganic Chemistry Laboratory, University of Oxford, South Parks Road, Oxford OX1 3QR, UK

5 Laboratoire de Chimie et Biologie des Métaux, Université Grenoble Alpes, CNRS, CEA, 17 rue des Martyrs, 38054 Grenoble, France 